$\mathrm{Oz}$

$1-1-1998$

\title{
Materializing through the Skylight
}

Wayne Michael Charney

charney@ksu.edu

Follow this and additional works at: https://newprairiepress.org/oz

Part of the Architecture Commons

(c) (i) $(9)$

This work is licensed under a Creative Commons Attribution-Noncommercial-No Derivative Works 4.0 License.

\section{Recommended Citation}

Charney, Wayne Michael (1998) "Materializing through the Skylight," Oz: Vol. 20. https://doi.org/10.4148/ 2378-5853.1323

This Article is brought to you for free and open access by New Prairie Press. It has been accepted for inclusion in Oz by an authorized administrator of New Prairie Press. For more information, please contact cads@k-state.edu. 


\section{Materializing Through The Skylight: How the Crystal Palace Acquired its Architectural Significance}

\author{
Wayne Michael Charney
}

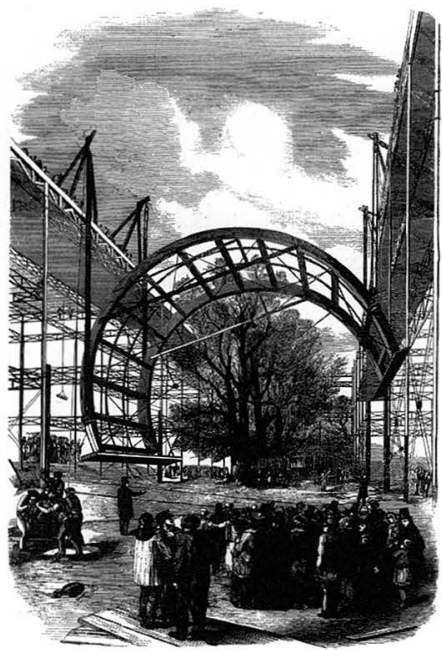

The raising of transept ribs as described in The London Illustrated News, December 1850.
Whether or not any structure built for a world's fair can ever hope to aspire to any sort of enduring architectural significance that extends well beyond the short life span of the exposition for which it was built is a question that has already been much debated and perhaps settled in the affirmative especially for some of the more visually exciting and experimental contemporary exhibition pavilions. Until recently, however, we had generally agreed that exposition buildings, because of their very nature as temporary structures, could not ordinarily be expected to advance with great strides the state of the art and science of architecture. Such exposition buildings, rather, were intended to serve only the moment and with rare exception did any one of them stand out as an unprecedented or substantive architectural accomplishment. However, one very singular exception to this generalization comes to mind-the London Crystal Palace of 1851. It is this building, which housed the very first world's fair, and the continually changing attitudes toward it over the last century and a half that will serve as the nexus of our attempts to understand what it is that gives a a building architectural legitimacy, and how those precepts may change over time. So persistent and recurrent are references to the Crystal Palace in virtually all histories of modern architecture that we are necessarily compelled to decipher the dichotomy that exists between its original inception as utilitarian building versus its eventual interpretation as architecture.

Currently, the Crystal Palace is considered to be a remarkable and influential piece of architecture. It has, in fact, become somewhat standard practice for historians to label it a sort of prototype or great progenitor for all that later modern architecture that also employs metal-and-glass construction techniques in any conceptually significant way,. Although we fully realize that the development of 20thcentury architecture is much too complicated to be so simply stated and that the Crystal Palace stood on end does not render unto us the John Hancock Center or the Sears Tower, it is fundamentally true nonetheless that the Crystal Palace was the first magnificently large-scaled example of all those industrial processes and methods which are today so much a part of architectural construction practices. The Crystal Palace utilized standardized, prefabricated, mass produced, interchangeable parts. The logistics of construction were ingenious to the point that even the wooden planks which at first fenced in the construction site later found a practical purpose as floorboards within the finished exhibition hall. The monumentality of the construction task can be quantified: 3300 cast-iron columns fitted into a foundation of horizontal pipes which doubled as drainpipes, 2224 principal girders, 205 miles of wooden sash bars to hold 293,655 individual panes of glass in place. This 900,000 square-foot surface area of glass curtain wall and roof equalled one-third of England's total glass production just eleven years earlier in 1840. The Crystal Palace covered nearly 19 acres of land and enclosed 33 million cubic feet of space at a cost of about one penny per cubic foot. The structural details of the Crystal Palace foretold, too, many 20th-century construction techniques. Cross bracing of wrought-iron tie rods provided lateral stiffness along with a rudimentary form of portal bracing wherein columns were joined to trusses along their full depths, and the trusses themselves were cambered in a manner somewhat equivalent to today's prestressing techniques.

When it is neither the construction process nor a structural detail of the Crystal Palace which is assessed as its single most prophetic or significant architectural feature, then surely it is the building's final formal aspect or its stunning spatial effect to which we today turn to justify the Crystal Palace as a legitimate piece of architecture. It is just exactly because so much of its bold aesthetic, its transparent walls, its filigree structure and its spectacular lightflooded effects of materiality dissolving into atmosphere have all been revived countless times in the metal-and-glass architecture of this century now coming to a close that the Crystal Palace is able to claim an architectural noteworthiness. Indeed, in a culture that is today increasingly mesmerized by the virtual reality of things, Joseph Paxton, designer of the Crystal Palace, might be justifiably hailed as the originator of an incipient example of architectural intangibility; however, both he and most of his contemporaries judged the Crystal Palace to be not a masterful display of infinite architectural possibilities but a masterpiece of eminently practical 


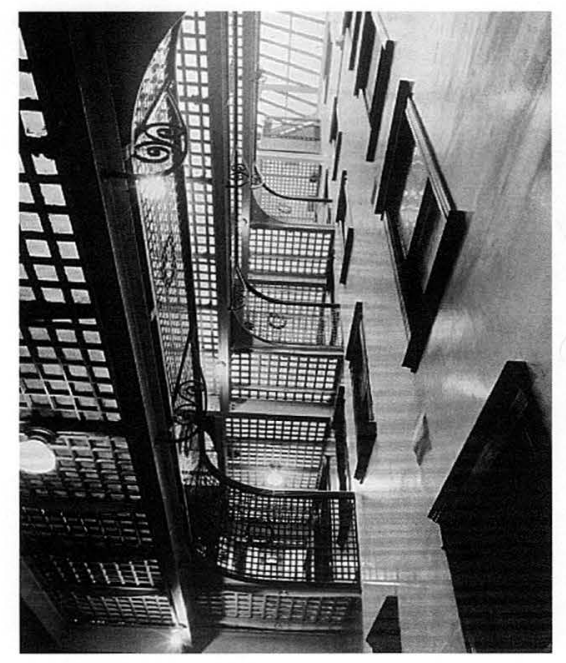

Turnock's Brewster Apartments. 1893. Photos courtesy of Carl W. Condit.

construction techniques and straightforward utilitarian building.

To the Victorian, truly valid architecture-that is, the high art of building - had to satisfy three major requirements: it had to be of a traditional building type, it had to have been constructed of traditional materials, and it had to convey in its final form a sense of monumentality or permanence. The Crystal Palace failed to meet all three of those criteria: it was an exposition building, not a temple or a palace or a tomb; it employed glass and metal almost entirely in its construction, not brick or stone; and its skeletal nature made it look impermanent and fragile, its glass skin denied its bulk and any concomitant substance, and its very purpose required that it stand temporarily for only a few months, not for centuries. How then can we explain this paradox? Is the Crystal Palace to be regarded as architecture or as mere building?

Our present attitude regarding that which is architecture differs markedly from, or is at least significantly broader than, what Victorians would have defined as architecture. The 19th- century historian James Fergusson, who in 1862 published his classic History of the Modern Styles of Architecture, best represents the standard Victorian interpretation of the question, "Though an admirable piece of Civil Engineering," he wrote, "[the Crystal Palace] had no claim to be considered as an architectural design." ${ }^{2}$ In Fergusson's mind, the Crystal Palace lacked some of the crucial elements of true architecture, specifically ornament and a sense of durability. It was seriously deficient in decoration and solidity, and Fergusson doubted whether any glass building could ever impart the quality of permanence which, he argued, was the most indispensable characteristic of architecture in the strictest sense.

Actually, it was the great art critic John Ruskin who had been the first to challenge those who had cloaked the Crystal Palace with the mantle of architectural respectability. As he so succinctly phrased it, the Crystal Palace was "neither a palace nor of crystal." He protested against the delusion that Paxton had created a new style of architecture when he had merely magnified a conservatory. Glass and iron, wrote Ruskin in his 1851 edition of Stones of Venice, were "eternally separated from all good and great things by a gulph which not all the tubular bridges nor engineering of ten thousand nineteenth centuries cast into one great bronze-foreheaded century could ever overpass one inch of." 4 It remains a marvelous sentence to utter even to this day, but certainly it no longer stands as the universal and irrevocable law which Ruskin once thought it to be. In fact, as Nikolaus Pevsner has noted, within that small group of very few buildings of the 1850s which did employ the Crystal Palace aesthetic and yet were labeled architecture with a capital $\mathrm{A}$, there exists one to which Ruskin himself had helped (at least indirectly) to give form-the University Museum at Oxford. ${ }^{5}$ Its wonderful metal-and-glass exhibi-tion courtyard captures some of the feeling that its greater progenitor must have conveyed. Ruskin, therefore, could not have been so blind to the readily discernible architectonic possibilities inherent within the Crystal Palace after all. ${ }^{6}$

A few of his contemporaries were even more willing to concede to Paxton's achievement a modicum of architectural legitimacy. Thomas Harris, an

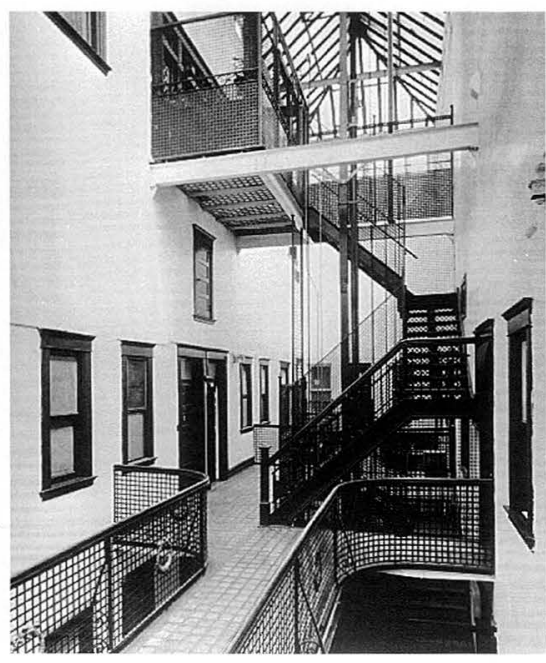

apparently outlandish High Victorian Gothic architect, wrote in 1862 that a "new style of architecture, as remarkable as any of its predecessors, may be considered to have been inaugurated" in the Crystal Palace. Incidentally, Harris titled his article "What is Architecture?"7 Sir George Gilbert Scott wrote in 1858 that the "triumph of modern metallic construction [was opening] out a perfectly new field for architectural development" in a most self-evident way. ${ }^{8}$ Yet in the final analysis both of these Gothic revivalists would probably have shied away from the use of Crystal Palace techniques except as an expediency in very rare or unusual commissions.

Horace Greeley, the prodigious American newspaper editor and one of the official observers for the United States at the 1851 Fair, summed up the whole matter in this manner:

The Crystal Palace, which covers and protects all, is better than any one thing it contains, it is really a fairy wonder, and is a work of inestimable value as a suggestion for future architecture... Depend upon it, stone and timber will have to stand back. for iron and glass hereafter, to an extent 
not yet conceivable. The triumph of Francisco, Willis Polk, who was not Paxton is perfect, and heralds a licensed to practice architecture yet revolution. ${ }^{9}$

Thus, Greeley did not speak of the Crystal Palace as a tangibly pedantic piece of architecture itself existing within pinpointed temporal limits; but he invested it, instead, within an almost mythic power that could conjure up apparitions of some future course of development for modern architecture. Nevertheless, the Crystal Palace apparently delighted Greeley and his contemporaries in a manner which was typical of even the best derivative works of architecture of that day.

And so for many years the Crystal Palace remained a guilty pleasure, not quite architecture and yet something a bit more special than the usual greenhouse or railroad shed. When was it exactly that the Crystal Palace achieved its legitimacy as architecture, when did the fairy tale vision acquire credible substance? The apotheosis of the Crystal Palace from artifact of 19th-century building craft to paragon of high building art paralleled to a remarkably close degree the changing definition of architecture itself in the modern era. All the while, the Crystal Palace served as a sort of touchstone of modernity. When the Chicago School began to heal the great schism, or "gulph" as Ruskin had called it, between architecture and engineering, Crystal Palace techniques emerged as predominant elements of that mediating architectural vocabulary. The Chicago School is replete with examples of glass-covered atria and courtyards. Even a mediocre Chicago School architect such as Enoch Hill Turnock, an obscure product of William LeBaron Jenney's office, could produce a masterpiece which paid homage to Paxton's great structure. Turnock's 1893 design for the Lincoln Park Palace Apartments, now the Brewster Apartments, featured an airy, glass-topped atrium which was crisscrossed with footbridges paved holds claim to the design of what many historians regard to be the first true glass curtain wall in a large urban structure, acknowledged the debt he owed to Paxton's building when he used the words "The Crystal Palace" to caption an early perspective of his Hallidie Building, which was itself roundly belittled as "frontless" by critics of that time. They ridiculed its lack of propriety and called its fragility dangerous. ${ }^{11}$

At about this same time, Sir Edwin Lutyens, an English architect practicing in an eccentric historicizing mode, could poke fun at that now worn and musty anachronism of the still surviving reincarnation of the Crystal Palace at Sydenham. To the query of what should be done with the glass hall (its form swollen by three transepts and barrel vaults over all) Lutyens wryly responded, "Put it under glass." ${ }^{12}$ By the early 1900 s the Crystal Palace had become a sort of oddity or curiosity in a world now boiling over once more with all manner of historical revivals.

The redefinition of architecture has been an intrinsic part of the development of a modern 20th-century style, and this redefinition reached its most crucial phase with the formulation and dissemination of the tenets of modern design in the 1920s and 1930s. Assessments of the architectural import of the Crystal Palace during those same years perfectly reflected the corpus of concurrent reformulations of modern architectural canon. That is to say, the architectural legitimacy of the Crystal Palace was coincident with and, in fact, mutually dependent upon the justification and acceptance of the socalled International Style. In his 1940 book An Introduction to Modern Architecture, J. M. Richards, noted critic and editor of the Architectural Review, claimed that the 1851 London Crystal Palace "was only rediscovered as a thing of architectural significance by modern architects in later years." ${ }^{13}$ Indeed, while this first heroic generation of modern architects was generally reluctant to acknowledge any historicism in their work at all, the Crystal Palace was the one exception to their rule. No one less than Le Corbusier himself invoked the majesty and hard won respect of the Crystal Palace in order to inveigh against all of those academics and reactionaries who had accused him of dementia and the International Style of monotony. Le Corbusier wrote:

When, two years ago, I saw the Crystal Palace for the last time, I could not tear my eyes from the spectacle of its triumphant harmony. The lesson was so tremendou that it made me feel how puny our own attempts still are. But, I felt, too, how eminently justifiable and practicable our proposals are, if only they get a chance. ${ }^{14}$

Le Corbusier claimed that the reactionary spirit was crushing a new modern style, and he felt the outrage all the more strongly because the Crystal Palace no longer survived as a witness in his defense. The Crystal Palace had been destroyed by fire on the evening of 30 November 1936, and Le Corbusier's words, as recorded in Architectural Review, stood as a eulogy. He concluded his tribute with these visionary meditations:

... we have more need than ever of the assurance that we can forge ahead-more need than ever of not being afraid to see too clearly or too big.

That "uniformity," of which so much has been heard among the various arguments used to assail the New Architecture, offered a convincing example of its plastic possibilities in the Crystal Palace, where all was grandeur and simp! icity. ${ }^{15}$

Others, too, paid their respects to the legendary Crystal Palace. P. Morton Shand criticized the press for treating the building's demise as a local sensation which barely exceeded in its level of interest the bulk of daily journalistic dram. It was not, he claimed, "a fossilized museum piece...but a precept as inspiring as the Parthenon, an exemplar vital as the Pont du Gard." ${ }^{16}$ In short, Shand placed it amongst the great works of architecture, a work of architecture as much as Stonehenge or Ely Cathedral were works of architecture, complete with a fabled existence that transcended the corporeality of the materials out of which any of them had actually been built. The opening of the Crystal Palace on 1 May 1851 marked the beginning of a new architectural style in Shand's opinion. His views were reinforced by a spate of books with publication dates that clustered neatly around the year of the Crystal Palace's immolation. In his 1936 book Pioneers of the Modern Movement, Pevsner claimed that he had detected in the monumental Crystal Palace a new assertion of faith in iron construction as architecture; Sigfried Giedion extolled the hall's more visually dazzling aspects in his classic book Space, Time and Architecture of 1941; Christopher Hobhouse published his book entitled 1851 and the Crystal Palace in the year after the great fire; and Paxton's granddaughter, Violet Markham, wrote was then the definitive biography on her ancestor Paxton and the Bachelor Duke just one year before the fire. Incidentally, Markham opined that both her grandfather and his work had fallen into a state of oblivion. ${ }^{17}$

Obviously, that was not the case, for the attention paid to the now vanished Crystal Palace in the decade of its destruction probably helped to solidify its architectural character as much as the grudging but growing acceptance of the International Style was serving to legitimize it. The 1930s was a decade of intense experimentation on and investigation into the matter of glass in architecture. The era was dubbed "The Age of Glass." 18 Therefore, in no small measure did the acceptance of glass as part and parcel of the International Style baggage as well as its acceptance at long last as a respectable building material con- 


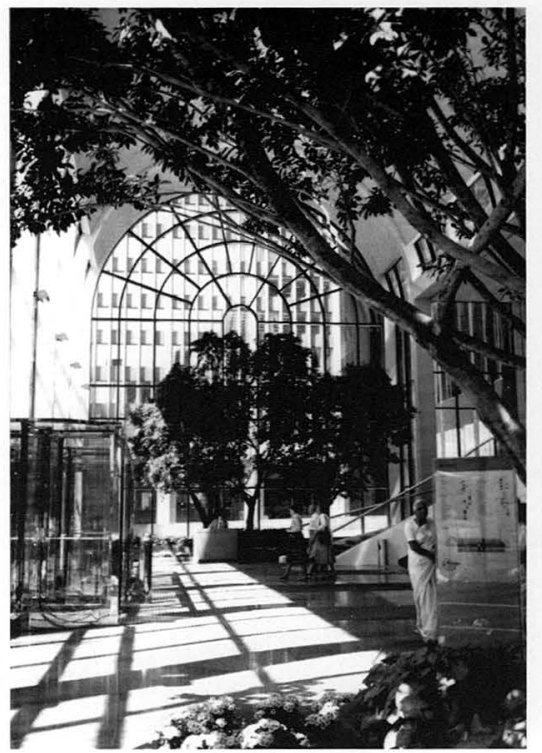

Skidmore, Owings, and Merrill. Sears Tower Entry Pavilion. 1985.

tribute to the interpretation of the Crystal Palace as important architecturally.

By 1950, when both Philip Johnson and Ludwig Mies van der Rohe had completed their landmark glass houses, no one would demand any longer that the Crystal Palace had to justify itself as architecture. The legacy of the Crystal Palace, as embodied in its particular brand of modern aesthetic sensibilities and its construction techniques alike, was by this time too much a part of contemporary architecture. Indeed, R. Furneaux Jordan titled his Crystal Palace centennial anniversary article in the RIBA Journal "The Architectural Significance of 1851." ${ }^{\prime 19}$

The Crystal Palace had, fortunately, escaped history's relegation of it to utilitarian anonymity, but it still had not yet escaped attempts to mimic its significance. Such parodies furnish proof to many architectural observers of the shallow faddishness and trivialized insubstantiality of that contemporary body of architecture that has been called Post-Modernism. For instance, while lauded at the time, Philip Johnson's 1976 near-literal translation of the

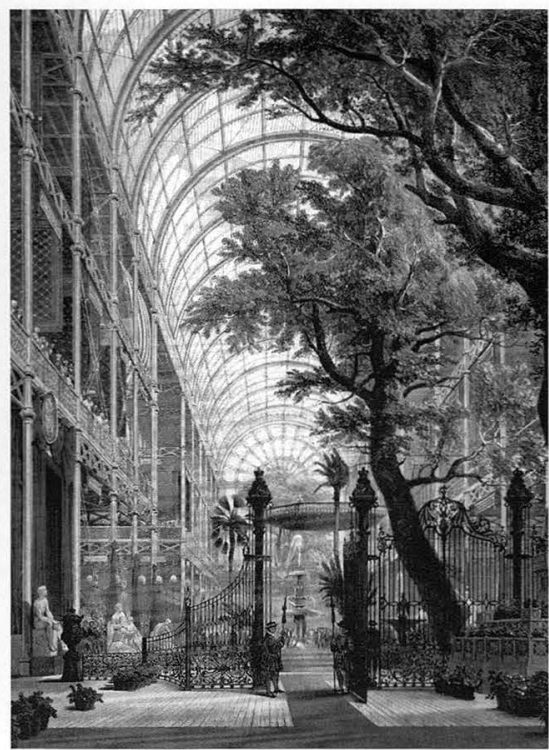

Transept of the Crystal Palace awaiting the entry of Queen Victoria. 1 May 1851.

Crystal Palace into the Garden Grove Crystal Cathedral is, at present, barely perceptible as a force that has had any sort of influence at all in molding contemporary architectural preferences. Consider, as well, the 1985 glassarcaded addition to the Sears Tower. This entry pavilion seems to stand timidly and uncomfortably next to the glass behemoth it serves; it is hardly the grand gesture the architects must have intended because both its scale and its historicizing form appear so discordant and feeble when juxtaposed with what was, up until 1997, the world's tallest building. The parody comes all the more sharply into focus when one realizes that both parts of the Sears Tower were designed by the same firm and that that firm, Skidmore, Owings and Merrill, once the bastion of a duly inherited set of idealistic Miesian principles, had apparently felt compelled to compromise its integrity in order to stay in vogue. In the process, the lessons which could have been learned from the Crystal Palace have been reduced to a sort of architectural trivia. This satire became even more absurd when, in 1984, the new computer merchandise mart in Dallas was completed. So exacting a replica of Paxton's great

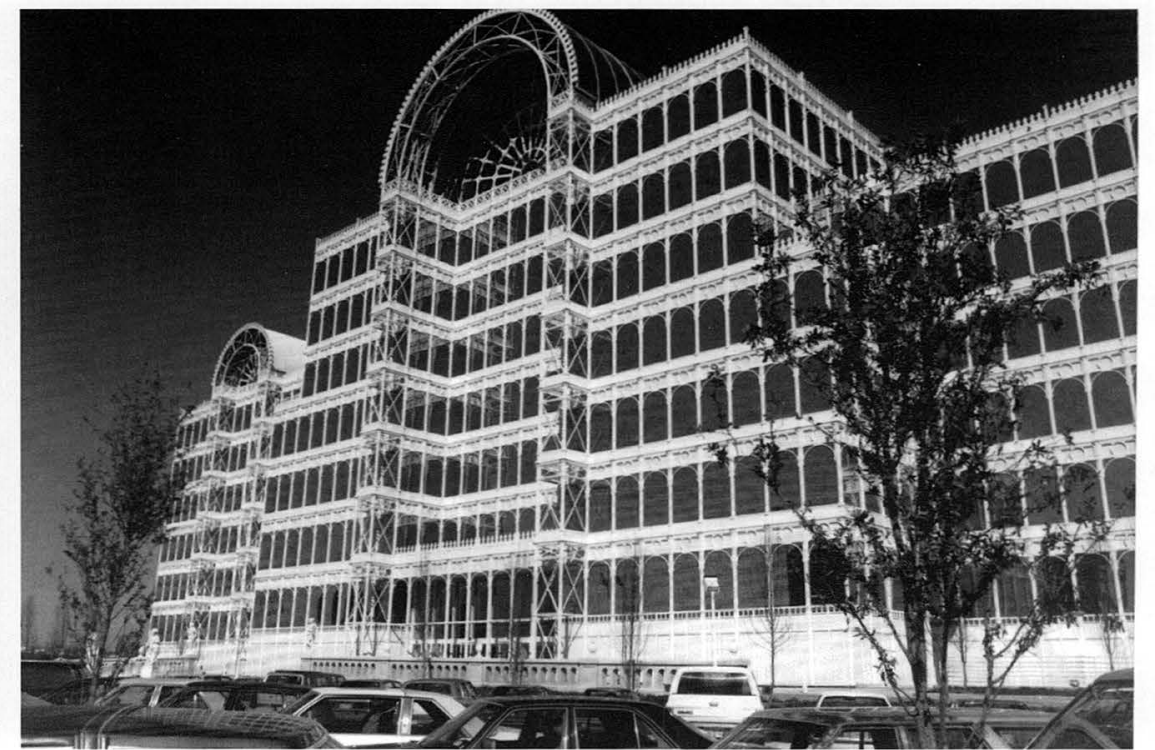

Dallas Infomart, 1984

canonical work is this Infomart (it is, as a matter of fact, clad with silver reflective glazing and cast aluminum panels that mimic the original in benumbingly finite detail) that one is stupefied by the glaring absence of any real wit that might have otherwise playfully exploited the irony of housing cyber technology showrooms in a "virtual" copy of the authentic Crystal Palace exhibition hall. ${ }^{20}$

At the close of the present century, the specter of the Crystal Palace has once more loomed large and architecturally relevant in its ability to exert still very palpable influence upon the critically noteworthy and, therefore, highly credible work of the so-called British "high-tech" architects. As the Richard Rogers design for the new Lloyd's of London took shape in the early 1980s, it was apparent to even the most casual observer that a Crystal Palace parti sat at the very heart of an otherwise technologically radical building design. Preserved, even cocooned, deep within a external perimeter committed formally to the exposition of mechanical systems and service equipment-stair towers and 33 prefabricated "clip-on" toilet modules so new in concept that they could only be built by a contractor who normally specialized in the fabrication of vessels for the nuclear industry - was the irreducible core of the Crystal Palace, a rather conservative-looking barrelvaulted atrium space endeavoring to replicate the most identifiable qualities of Paxton's venerable old temple made of glass. ${ }^{21}$ Paradoxically, the spitting image of the rather dowdy old lady of the Crystal Palace herself held court at the center of all that new technological flux emanating from Rogers's agile imagination. What had been in the mid-19th century undeniably nonarchitectural was now the only thing of real, immutable substance and architectural validity within an otherwise indeterminate proposition for some sort of "high-tech" paradigm. When Queen Elizabeth II, in eery verisimilitude to her illustrious predecessor Queen Victoria at the opening of the London Crystal Palace, officially dedicated the new insurance headquarters in November 1986, the picture was complete and the odyssey of the Crystal Palace had come nearly full circle. ${ }^{22}$

In the end it is appropriate that the Crystal Palace should have been 
invested with its last iota of architectural respectability from yet another experimental exhibition pavilion built by the British themselves for yet another world's fair. In explaining his concept for the British Pavilion at the 1992 Seville Expo, Nicholas Grimshaw unabashedly and forthrightly hailed Paxton's work as the great progenitor of nearly all contemporary architecture of any cutting-edge significance. He said, "A lot of architects who are practising traditional British architecture, such as Foster, Rogers and Hopkins, have Paxton's Crystal Palace in their background as a root building. ${ }^{.23}$ To the outside of this technoid-age glass-box offshoot of the Crystal Palace Grimshaw grafted energy-saving gadgets including roof sails with integrated solar cells and a water wall by which the front facade of the pavilion was cooled with curtains of water cascading over its surface. Indeed, because Britain was a maritime nation-naval battles, shipping, the Thames, the Channel Tunnel-all throughout its long history, water became the theme for Grimshaw's imaginative building design in general. Furthermore, the interior volume of his glass pavilion he likened to a cathedral, and he praised the enormous human effort that was poured into the building's design and fabrication. Grimshaw regarded his work, on what was admittedly nothing more than a "demonstration building," to be "a way of pulling us back to the real values of architecture" after an appalling period of regrettable architectural taste in the 1980 s. ${ }^{24} \mathrm{He}$ claimed that his design had come to represent the spirit of the present age.

In this respect Grimshaw was aspiring to re-engage the very purpose and ultimate objective of the London Crystal Palace. For if the Crystal Palace set any precedent at all in the minds of the Victorians, it was not as the objectified manifesto for some new style of architecture; but rather its clever exploitation of available technology was seen as the most expeditious means by which the English could quickly and economically reformulate in one place at one particular point in time the accumulated essence of earlier, more substantive English cultural achievements including, of course, those achievements in the realm of bona-fide, historically ratified works of architecture. While the opening of the London Crystal held the world's undivided attention in May 1851, the following lines of poetry were circulated among the masses to describe the momentous occasion:

\section{As I slept,}

I dreamt I was within a temple made of glass,

In which there were more images

Of gold, standing in sundry stages

In some rich tabernacle,

And with more jewels, more pinnacles,

And more curious portraitures,

And quaint manner of figures

Of gold work, than I saw ever

Then saw I stand on either side, Straight down to the doors wide From the dais many a pillar Of metal that shone out full and clear.

Then gan I look about, and see That there came entring in the hall A right great company withal, And that of sundry regions

Of all kinds of conditions

That dwell in earth beneath the moon, Poor and rich.

\section{Such a great congregation}

Of folks as I saw roam about,

Some within and some without,

Was never seen nor shall be no more!

These elegiac bits of verse, from a much longer poem entitled "The House of Fame," were written by Geoffrey Chaucer in 1372! Now, Chaucer was hardly a visionary who could foresee the world renowned status of his nation at some distant future point in time. To the contrary, it turns out that these fragments of the heroic poet's work had been cut apart, reshuffled, and then reconstituted by certain Victorian literati to describe more fittingly the sensations

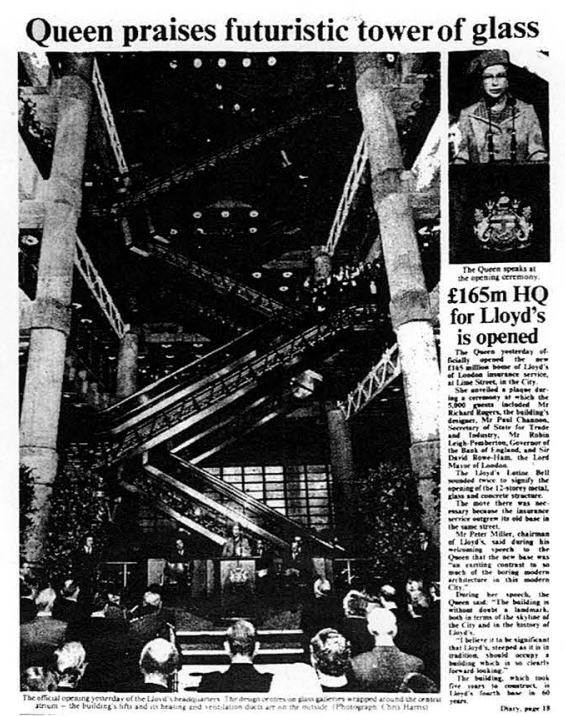

Queen Elizabeth II officially dedicates Richard Roger's Lloyd's of London. The Times, 19 November 1986.

of the Great Exhibition of 1851 in London. ${ }^{25}$ Their intent also was, in part, to link the Crystal Palace to England's grandest cultural traditions in general and to its most respectable building traditions in particular. While Chaucer's poem presumed, in actual fact, to describe a fabled Greek temple, a style of architecture that the poet had never seen firsthand, his imagery was necessarily derived from the most imposing sort of architecture he could have readily observed in his own time and locale-an English Gothic cathedral. ${ }^{26}$ Thus, when Chaucer spoke of those metal-like pillars that are so premonitory of the cast-iron columns of the Crystal Palace, he was actually envisioning the darker colonnettes of polished stone affixed to the main piers of a nave space like that at Salisbury. Similarly, chroniclers of the Crystal Palace adopted the entire lexicon of ecclesiastical architecture terms to describe its various elements - nave, side aisles, transept, gallery, and so on. The opening ceremony, at which were gathered the Queen, the Archbishop, and heroes and dignitaries from "sundry regions" the world over, culminated with the jubilant performance of the "Hallelujah Chorus" from Handel's
Messiah oratorio. It encapsulated, in one swelling lyrical evocation of all that was thoroughly English, that triumphant human effort that had also created the Crystal Palace. Surely, there was no more transcendent work of architecture in the world then when the Crystal Palace opened on 1 May 1851.

Chaucer had seemingly predicted it all; and in manipulating his vision, the Victorian admirers of the Crystal Palace simultaneously coupled this remarkable piece of mere engineering with both the most solid of English traditions and the most formidable of Western cultural cornerstones. Like the contemporary "high-tech" British architects who now imitate his methods and who polemicize for legitimacy in their works as well, Paxton exploited a fresh set of technical possibilities-in his case, metal-and-glass construction techniques-in order to materialize, out of nothing of apparent substance or real lasting importance, a grand synthesis of his age. His geniusindeed, the genius behind all true architecture-lay in the ability to invest old concepts with startling new power. 


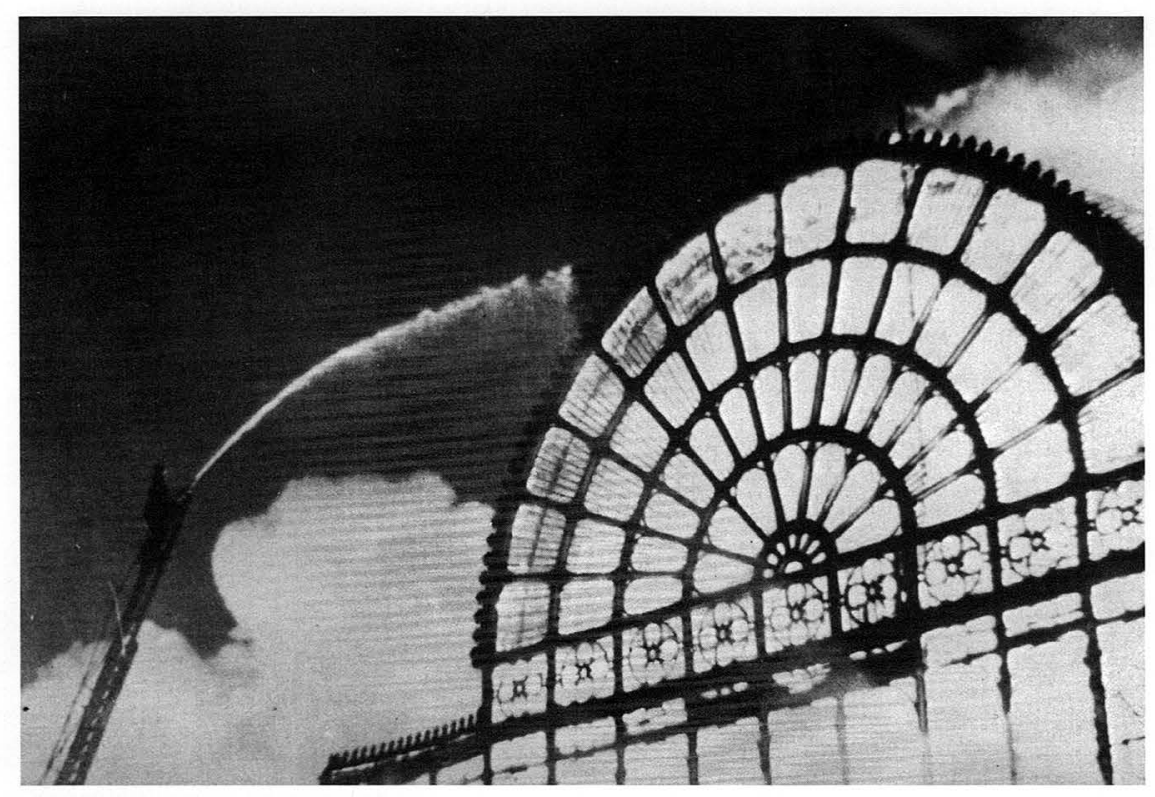

The Crystal Palace. Destroyed by fire, 30 November 1936.

Notes

1.Folke T. Kihlstedt, "The Crystal Palace," Scientific American 251 (October 1984): 133-139. Kihlstedt's article is the best of several recent studies which attempt to establish the architectural legitimacy of the Crystal Palace on the basis of its construction logistics and advanced structural techniques. Even earlier rediscoveries of the modern architectonic qualities of the Crystal Palace include: Nikolaus Pevsner, Pioneers of the Modern Movement, From William Morris to Walter Gropius (London: Faber and Faber, 1936); J. M. Richards, An Introduction to Modern Architecture (Harmondsworth: Penguin Books Ltd.,1940); Sigfried Giedion, Space, Time and Architecture (Cambridge, Massachusetts: Harvard University Press, 1941); and James M. Fitch, "The Palace, the Bridge and the Tower," Architectural Forum 87 (October 1947): 88-95.

2.James Fergusson, History of the Modern Styles of Architecture, second edition (London: John Murray, 1873), p. 556.

3.Ruskin quoted in Violet R. Markham, Paxton and the Bachelor Duke (London: Hodder and Stoughton, 1935), p. 220. 4.John Ruskin, The Stones of Venice (New York: John Wiley, 1851), p. 412.

5.Pevsner, p. 135.

6.Ruskin did, however, criticize the execution of Woodward's design for the Oxford University Museum. Admittedly, the building was for Ruskin more important as a cause - the revival of the Gothic_-than as an architectural design. Ruskin's influence on the Museum's final form was largely indirect the result of the effect of his writings on the architects. He did, however, contribute some decorative designs for the building. See Eve Blau, Ruskinian Gothic: The Archiure of Deane and Woodward, 1845-1861,(Princeton: Princeton University Press, 1982), especially pp. $67,72,78$

7.Thomas Harris, "What is Architecture?" Examples of the Architecture of the Victorian Age (London:Darton and Hodge, 1862),p. 57. 8.George Gilbert Scott, Remarks on Secular and Domestic Architecture (London:J. Murray, 1858), pp. 109-110.

9.Horace Greeley, Glances at Europe in a Series of Letters from Great Britain, France, Italy, Switzerland, Ec. (New York: Dewitt and Davenport, 1851), p. 19

10. "Synopsis of Building News," Inland Architect 20 (December 1892):58. Also see Carl W. Condit, The Chicago School of Architecture (Chicago: University of Chicago Press, 1964), pp. 157-158.

11.Keith W. Dills, "The Hallidie Building," Journal of the Society of Architectural Historians 30 (December 1971): 324,327. In something of a show of profound modesty, Polk's self-appraisal of his work of that of "master builder" rather than that of an "architect" would, therefore, tend to render his work something less than traditionally "architectural" in the lingering 19th-century sense of the word. Also see Nory Miller, "Down and Dirty in 1917," Progressive Architecture 62 (November 1981): 108.
12. Christopher Hussey, "The Personality of Sir Edwin Lutyens," RIBA Journal 76 (April 1969): 145

13.Richards, p. 66.

14.Le Corbusier, "A Tribute," Architectural Review 81 (February 1937): 72.

15.Ibid.16. P. Morton Shand, "The Crystal Palace as Structure and Precedent," Architectural Review 81 (February 1937): 65. 17.Markham, p. ix.

18.See, for example, "The Glass Age Arrives," Architectural Forum 68 (February 1938): supplement 17-28.

19. R. Furneaux Jordan, "The Architectural Significance of 1851," RIBA Journal 58 (July 1951): 340-348.

20. "Palatial Hall Design Spans the Centuries," Engineering News Record 213 (6 December 1984): 32-33,36. The Infomart, or more properly the International Information Processing Market Center, was designed by architect Martin C. Growald of Fort Worth, Texas. The building measures 492 feet by 540 feet in plan.

21. Alexander Tzonis and Liane Lefaivre, Architecture in Europe: Memory and Invention Since 1968 (London: Thames and Hudson Ltd., 1992), pp. 157-158.

22. "Queen praises futuristic tower of glass," The Times (19 November 1986): 24 .

23. Nicholas Grimshaw and Richard Haryott, "Solar-powered Pavilion," RIBA Journal 99 (October 1992): 32.

24. Ibid., p. 35.

25. Markham, p. 210.
26. B. G. Koonce, Chaucer and the Tradition of Fame: Symbolism in the "House of Fame" (Princeton: Princeton University Press, 1966), passim. 